\title{
RELAÇÕES DIALÓGICAS E PERSUASÃO
}

\section{DIALOGIC RELATIONS AND PERSUASION}

\section{Maria Felena Cruz Pistori*}

Pontifícia Universidade Católica de São Paulo, São Paulo, SP, Brasil

Resumo: Este artigo tem o objetivo de mostrar como conceitos da antiga Retórica, assim como noçōes e categorias da Análise Dialógica do Discurso (ADD), inspirada na obra de Bakhtin e o Círculo, podem ser compreendidos como fundamentação teóricometodológica para a análise da persuasão discursiva. Dois textos diferentes, de diferentes gêneros do discurso, são uitilizados para demonstrar a persuasão nas relaçōes dialógicas expressas por amplas e distintas esferas da atividade humana, em conexão com a organização da vida social, 0 espaço e tempo em que se inserem.

Palavras-chave: Retórica; Círculo de Bakhtin; Gêneros do discurso; Persuasão; Valores.

Abstract: This article aims to show how concepts from ancient Rhetoric, as well as Dialogic Discourse Analysis (DDA) notions and categories, inspired in the works of Bakhtin and the Circle, can be understood as theoretical-methodological basis for the analysis of persuasion in discourse. Two different texts, from different speech genres, are used as examples to demonstrate the persuasion in dialogic relationships expressed by broad and different spheres of human activity, in connection with the organization of social life, space and time.

Keywords: Rhetoric; The Bakhtin Circle; Speech Genres; Persuasion; Values.

* Pós-doutora pela Pontifícia Universidade Católica de São Paulo - PUC-SP, São Paulo, Brasil. (CNPq - Proc. 150095/2014-7); mhcpist@uol.com.br 
Linha D'Água (Online), São Paulo, v. 29, n. 2, p. 173-193, dez. 2016

\section{Introdução}

Este artigo tratará da argumentação a partir da teoria do discurso que se depreende da obra de Mikhail Bakhtin e o Círculo. Na realidade, a obra do Círculo não se constitui uma teoria da argumentação, nem mesmo se pretende uma teoria acabada do discurso ou da linguagem. Trata-se de um pensamento que se desenvolve e se complementa a partir de debates ocorridos em "círculos" de pensadores de diferentes áreas - filósofos, linguistas, estudiosos da literatura, músicos, etc., na década de 1920-1930, no período que se seguiu à Revolução Russa de 1917 (Cf. BRAIT, 1998, p. 158-173; FARACO, 2009, p. 9-44; ZANDWAIS, 2009, p. 97-116, entre outros). Desses debates resultaram importantes obras que comungam conceitos e noções familiares a todos os seus membros, particularmente Mikhail M. Bakhtin, Valentin N. Voloshínov e Pavel N. Medviédev. A obra que produziram, algumas delas cuja autoria ainda é disputada ${ }^{1}$, constitui-se um aparato teórico-epistemológico que, num primeiro momento, se julgou adequado sobretudo aos estudos literários. Hoje, no entanto, percebe-se que, por tratarem da palavra e do discurso não apenas na arte ou na poesia, mas também na vida, expressam noções e conceitos de grande força heurística para a compreensão da língua e da linguagem de modo geral. E é a este conjunto teórico-metodológico que têm se referido os estudiosos do discurso quando se referem à Análise Dialógica do Discurso (ADD).

Quanto à argumentação, é importante esclarecer que vamos tratar dela a partir das noções da antiga retórica, especialmente a aristotélica: "a faculdade de ver teoricamente o que, em cada caso, é capaz de gerar a persuasão" (Retórica, 1355b). Aristóteles é o responsável pela sistematização da disciplina nascida entre os gregos, por volta do séc. $\mathrm{V}$ aC; na verdade, a primeira disciplina do discurso que conhecemos no mundo ocidental. Inicialmente ligada aos sofistas, professores itinerantes que cobravam pelo ensino do modo de preparar discursos persuasivos nas diferentes cidades-estado da antiga Grécia, a retórica foi combatida por Platão em alguns de seus diálogos, como Fedro, Górgias, O sofista e Protágoras. Nele, sempre há uma crítica à relação não necessária entre retórica e verdade, pois ela

1 Não vamos nos deter na questão da autoria neste texto, questão que já rendeu numerosos e polêmicos estudos. Importa-nos a obra do Círculo como um todo. 
Linha D'Água (Online), São Paulo, v. 29, n. 2, p. 173-193, dez. 2016

estaria ligada ao engano e à opinião; mas é importante lembrar que tais objeções remetem a sua filosofia idealista como um todo (Cf. PISTORI, 2001, p. 43-47). E Henri-Irinée Marrou, historiador da educação na Antiguidade, nos lembra que conhecemos mal os sofistas, basicamente apenas através dos diálogos platônicos (Cf. 1990, p. 81-102).

Aristóteles, então, é o responsável por conceder um lugar à retórica na vida cotidiana do cidadão grego. Sua obra busca conciliar e organizar os pares antitéticos sobre os quais disputavam Platão e os sofistas: verdadeiro-verossímil, epistemedoxa. Para ele, haveria três níveis de conhecimento: um nível superior, da ordem da metafísica e das ciências, que se fundamentava sobre o necessário e verdadeiro; aquele da dialética, fundamentada no conhecimento provável; e a retórica, baseada na opinião. Esta última é de interesse de todo habitante da polis, pois dedica-se a deliberar sobre o útil ou prejudicial à cidade, o justo ou injusto de ações, o belo/o bom ou o feio/o mau de homens e feitos.

É basicamente a retórica aristotélica que herdamos. Ela ensina, assim como os tratados anteriores, que o discurso persuasivo se constrói a partir de cinco operações bastante conhecidas: inventio, dispositio, elocutio, memoria e actio. O Estagirita, porém, detém-se particularmente no estudo das provas - a inventio, e trata brevemente das demais operações no Livro III. Aliás, Aristóteles afirma que escreveu o tratado porque, embora se possa argumentar de modo espontâneo, sem estudar a “arte”, a investigação teórica e o estudo dos argumentos permitem fazê-lo mais eficientemente, com mais êxito.

Sobre a retórica antiga, há ainda outro dado interessante para este trabalho, sobretudo para relacioná-la, adiante, com a teoria dialógica do discurso. Trata-se da classificação dos gêneros dos discursos. Todos eles - o deliberativo, o judiciário e o deliberativo, envolviam a valoração de ações, homens ou acontecimentos, cada um tinha sua própria finalidade, tema, estilo e argumentos adequados, e dirigia-se a um auditório definido pela esfera de atividade em que era proferido. Assim, o gênero judiciário referia-se a fatos passados com o fim de acusar ou defender as partes, considerando o que era justo ou injusto, e seu auditório eram o juiz e os jurados. O discurso do gênero deliberativo dirigia-se à assembleia dos cidadãos, visava ao futuro, aconselhando ou não a tomada de decisões para a administração 
Linha D'Água (Online), São Paulo, v. 29, n. 2, p. 173-193, dez. 2016

da cidade, conforme fossem consideradas úteis ou prejudiciais; e o gênero epidítico elogiava ou censurava homens e feitos presentes, julgando-os como bons/belos ou maus/feios, diante de um auditório de pessoas comuns.

Nesta introdução, queremos ainda chamar a atenção para dois importantes aspectos da retórica: em primeiro lugar, sua função de exercício democrático, presente na Grécia antiga, mas que, na atualidade, apenas pode se concretizar em sociedades também democráticas; e, em segundo, o fato de que o discurso retórico defende valores, como já afirmava Aristóteles ao justificar o tratado e dar-lhe importância:

A retórica é útil, porque o verdadeiro e o justo são, por natureza, melhores que seus contrários. Donde se segue que, se as decisões não forem proferidas como convém, o verdadeiro e o justo serão necessariamente sacrificados: resultado este digno de censura (1355a).

[...] seria absurdo que a incapacidade de defesa física fosse desonrosa, e o não fosse a incapacidade de defesa verbal, uma vez que esta é mais próxima do homem do que o uso da força física (1355a).

Assim, neste trabalho temos o objetivo de mostrar como a antiga disciplina e a teoria dialógica do Círculo podem se aliar na compreensão da argumentação, já que, como afirma Bialostosky (2004), ambas tratam do discurso: a primeira com o foco no argumento, a segunda, no enunciado concreto. Passamos pois, no próximo item, a detalhar alguns dos aspectos que tanto definem a segunda como, simultaneamente, se revelam bastante produtivos para a análise e interpretação do discurso argumentativo. A seguir, mostraremos praticamente essa aliança por meio da análise de dois textos pertencentes a gêneros diferentes: um artigo de opinião e uma sentença judicial. E, nas considerações finais, refletiremos acerca da produtividade dos conceitos dialógicos e retóricos na compreensão do discurso de modo geral, mas destacando aqui os modos como os efeitos de sentido persuasivos foram construídos nos enunciados analisados. 
Linha D'Água (Online), São Paulo, v. 29, n. 2, p. 173-193, dez. 2016

\section{A teoria dialógica do discurso}

Inicialmente, a nosso ver, é a questão dos valores que vai nos permitir o diálogo entre a antiga disciplina com os textos do Círculo. Na verdade, às vezes nos parece que os valores se revestem até de maior importância na obra bakhtiniana do que na antiga retórica. Afirmamos isso porque os autores russos estão sempre nos lembrando que nossos enunciados nunca são neutros, mas expressam posicionamentos e, de alguma forma, sempre respondem a outros posicionamentos. Como Bakhtin afirma no ensaio $O$ problema do texto na linguística, na filologia e em outras ciências humanas, tratando do enunciado como expressão da língua viva: "Só o enunciado pode ser verdadeiro (ou não verdadeiro), correto (falso), belo, justo, etc." (2006, p. 329). Ou em Marxismo e filosofia da linguagem, destacando também a linguagem no uso cotidiano:

Não são palavras o que pronunciamos ou escutamos, mas verdades ou mentiras, coisas boas ou más, importantes ou triviais, agradáveis ou desagradáveis, etc.. A palavra está sempre carregada de um conteúdo ou de um sentido ideológico ou vivencial (BAKHTIN/VOLOCHÍNOV, 1981, p. 95).

E a obra bakhtiniana esclarece que os posicionamentos se expressam por meio da entonação expressiva, "traço constitutivo do enunciado" (BAKHTIN, 2006, p. 290), já que o falante se relaciona valorativa e emocionalmente com o objeto de sua fala: tal relação estabelece a ligação entre língua e vida. Mas, na realidade, na obra do Círculo a avaliação é vista ainda de forma mais ampla, não parte apenas do falante, pois toda compreensão envolve avaliação. Isto é,

... a compreensão é uma resposta a um signo por meio de signos. E essa cadeia de criatividade e de compreensão ideológicas, deslocando-se de signo em signo para um novo signo, é única e contínua: de um elo de natureza semiótica (e, portanto, também de natureza material) passamos sem interrupção para um outro elo de natureza estritamente idêntica (BAKHTIN/ VOLOCHÍNOV, 1981, p. 34).

Dessa forma, a compreensão é uma resposta, é parte de um elo semiótico ininterrupto de respostas, participa de um diálogo contínuo que se desloca de um 
Linha D'Água (Online), São Paulo, v. 29, n. 2, p. 173-193, dez. 2016

signo ideológico a outro, mesmo que tais respostas não se apresentem explicitamente por meio de uma expressão externa (cf. 2006, p. 298). É justamente isso que constitui a dialogia bakhtiniana. Como explicam Bakhtin/Volochínov [1929], em Marxismo e filosofia da linguagem, trata-se do “diálogo' num sentido amplo, [...] não apenas a interação face a face, mas toda comunicação verbal, de qualquer tipo que seja", na medida em que qualquer enunciação sempre "responde a alguma coisa, refuta, confirma, antecipa as respostas e objeções potenciais, procura apoio, etc." (1981, p. 123). A interação verbal é o fenômeno social que constitui o locutor e o interlocutor, sujeitos da enunciação, e o diálogo é a verdadeira substância da língua.

Importante destacar que esse diálogo ininterrupto se constitui nas relações dialógicas, também valorativas, podendo ocorrer não apenas entre enunciados em presença, mas também passados ou futuros, constituindo-lhes o sentido. Além disso, ocorrem a "qualquer parte significante do enunciado, inclusive a uma palavra isolada, caso esta não seja interpretada como palavra impessoal da língua, mas como signo da posição semântica de um outro, como representante do enunciado de um outro, ou seja, se ouvimos nela a voz do outro" (BAKHTIN, 2008, p. 210; grifos nossos). Assim, embora pertençam ao campo do discurso, não pertencem a um campo puramente linguístico do seu estudo (BAKHTIN, 2008, p. 208), visto que o sentido do enunciado depreende-se também das condições em que é produzido, do modo como dialoga com as condições sociais, históricas, políticas e culturais, e das próprias condições da interação verbal, da esfera de atividade de que participa, da relação entre falantes - de hierarquia, igualdade, familiaridade, etc.. Aliás, é sempre importante lembrar que, no pensamento bakhtiniano, a abordagem do discurso é proposta em sua integridade concreta e viva, o discurso situado espacial e temporalmente, com um autor e um destinatário, cujo sentido é dado na interação do verbal com o extraverbal (cf. Bakhtin, 2008, p. 207). E ainda que, na perspectiva dialógica, não se considera a distinção enunciação e enunciado: trabalha-se com o enunciado concreto.

Considerando que cada esfera de atividade humana tem seu próprio modo de encarar (refletir e refratar) a realidade, expressando-a e expressando-se nela diferentemente, outra categoria bakhtiniana fundamental para apreendermos o 
Linha D'Água (Online), São Paulo, v. 29, n. 2, p. 173-193, dez. 2016

sentido e a argumentação de qualquer enunciado é a de gênero discursivo ${ }^{2}$. Amplamente divulgado entre estudiosos, o ensaio Os gêneros do discurso foi escrito por Bakhtin entre 1951-53 e publicado na Rússia pela primeira vez numa coletânea em 1979. Nele o filósofo russo retoma a noção elaborada pelos membros do Círculo ao longo de cinquenta anos e cujo parentesco com a noção de gênero na antiga retórica já foi ressaltado por alguns autores, inclusive brasileiros (Cf. MACHADO, 2008, p. 151-166; ROJO, 2008, p. 73-108). No conhecido texto, Bakhtin afirma que "cada enunciado particular é individual, mas cada campo [esfera] de utilização da língua elabora seus tipos relativamente estáveis de enunciados, os quais denominamos gêneros do discurso" (2006, p. 261-262). Destaca, então, os três elementos indissoluvelmente ligados no todo do enunciado que caracterizam o gênero: o conteúdo temático, o estilo e a composição, que se expressam de modo particular nas diferentes "esferas [ou campos] da atividade humana", social, cultural e historicamente consideradas (p. 265). O ensaio aprofunda todas essas noções e sua leitura é imprescindível a qualquer analista do discurso.

No entanto, outro texto menos conhecido auxilia-nos neste trabalho para refletirmos ainda sobre a noção de gênero do discurso: o capítulo Os elementos da construção artística, em $O$ método formal nos estudos literários. Introdução crítica a uma poética sociológica, de P. N. Medviédev (2012, p. 193-207), publicado pela primeira vez em $1928^{3}$. Encontra-se aí relevante reflexão para bem entendermos o conceito, pois o autor chama a atenção para o fato de que os gêneros se caracterizam por uma dupla orientação dialógica, em íntima e tensa correlação: a primeira é o diálogo voltado para o exterior do enunciado concreto e relacionado à vida tempo, espaço e esfera ideológica definidos; a segunda, voltada para o interior, está relacionada às formas, estruturas e conteúdo temático do enunciado. Continuando, Medviédev esclarece que cada gênero é capaz de controlar apenas alguns aspectos

2 Para complementar e aprofundar a noção de gênero do discurso no Círculo de Bakhtin, ver BRAIT; PISTORI, 2012, p. 371-401.

3 É importante observar que Medviédev está se contrapondo aos estudos literários realizados pelos formalistas russos, que têm como objeto a linguagem poética, preferentemente em seus aspectos formais: é apenas através deles que procuram depreender o gênero da obra. Medviédev, ao contrário, insiste na necessidade de se considerar a totalidade concluída e solucionada da obra, realizada por sujeitos socialmente organizados, para dela se depreender o gênero. 
definidos da realidade. Assim, cada um deles "possui certos princípios de seleção, determinadas formas de visão e de compreensão dessa realidade, certos graus na extensão de sua apreensão e na profundidade de penetração nela” (2012, p. 196), acessíveis apenas a ele. Enfim, é o gênero que dá forma à obra; seus elementos estruturais, assim como a seleção dos recursos lexicais e gramaticais expressam a relação valorativa do locutor com o objeto do discurso, e só podem ser compreendidos em conjunto e na relação com o gênero. Disso decorre que há uma clara articulação entre visão de mundo e gênero, exatamente na medida em que o conteúdo temático de um enunciado é inseparável das circunstâncias de lugar e de tempo, é orientado pela realidade circundante. E justamente porque as circunstâncias sociais, históricas, culturais, políticas, geográficas, etc. são dinâmicas, não é possível fazermos uma classificação completa dos gêneros, que estão sempre sujeitos a modificações, não são estanques.

Finalmente, devemos pensar metodologicamente como realizar a análise a partir dessa teoria. Se a própria observação do modo como os membros do Círculo apresentam suas análises em obras como Problemas da poética de Dostoiérski, por exemplo, revela um procedimento metodológico exemplar, coerente com os conceitos e categorias que levantam, os passos propostos por Bakhtin/Volochínov para o estudo da língua em Marxismo e filosofia da linguagem explicitam o procedimento, cujo estudo deve acompanhar a seguinte ordem metodológica:

1. As formas e os tipos de interação verbal em ligação com as condições concretas em que se realiza.

2. As formas das distintas enunciações, dos atos de fala isolados, em ligação estreita com a interação de que constituem os elementos, isto é, as categorias de atos de fala na vida e na criação ideológica que se prestam a uma determinação pela interação verbal

3. A partir daí, exame das formas da língua na sua interpretação linguística habitual (BAKHTIN/VOLOCHINOV, 1981, p. 124).

Concluindo essa breve apresentação do que se tem conhecido como teoria dialógica do discurso, transcrevemos as palavras de Brait, que, a nosso ver, bem a resumem: 
Linha D'Água (Online), São Paulo, v. 29, n. 2, p. 173-193, dez. 2016

\begin{abstract}
Sem querer (e sem poder) estabelecer uma definição fechada do que seria essa análise/teoria dialógica do discurso, uma vez que esse fechamento significaria uma contradição em relação aos termos que a postulam, é possível explicitar seu embasamento constitutivo, ou seja, a indissolúvel ligação entre língua, linguagens, história e sujeitos que instaura os estudos da linguagem como lugares de produção de conhecimento de forma comprometida, responsável, e não apenas como procedimento submetido a teorias e metodologias dominantes em determinadas épocas. Mais ainda, esse embasamento constitutivo diz respeito a uma concepção de linguagem, de construção e produção de sentidos necessariamente apoiadas nas relações discursivas empreendidas por sujeitos historicamente situados (BRAIT, 2008, p. 10).
\end{abstract}

\title{
2 A argumentação em dois gêneros distintos
}

A noção de gênero do discurso, na perspectiva dialógica, é de importância fulcral. Daí que apresentamos a seguir dois textos de gêneros e esferas de atividade distintas: do campo jornalístico, um artigo de opinião; da esfera de atividade jurídica, uma sentença judicial.

\section{1 artigo de opinião}

\section{Shakespeare disse tudo ${ }^{4}$}

$\mathrm{Na}$ véspera de 11 de agosto é bom lembrar que William Shakespeare, há mais de 500 anos, fez críticas definitivas aos advogados como categoria profissional.

Considerando a defesa de criminosos, a participação nos controvertidos e explosivos casos de família, as manifestações em favor de figurões da política execrados pela mídia, os advogados são alvos fáceis da crítica. Mas foi o Bardo quem deu a palavra mais dura: "Para resolver os problemas do reino é necessário, em primeiro lugar, matar todos os advogados!"

4 Folha de S. Paulo, Cotidiano, - 10/08/1996. http://wwwl.folha.vol.com.br/ $\mathrm{fsp} / 1996 / 8 / 10 /$ cotidiano/9.html Acesso em 03 de agosto de 2015. 
A agressão shakespeariana está na segunda parte do Henrique $6^{\circ}$, posta na voz de um de seus personagens. Foi seguida por número infindável de peças, filmes, anedotas e narrativas que espelham a secular incompreensão com o papel dos advogados. Eles sabem que não há modo de se livrarem das críticas. Persistem na missão de porta-vozes da sociedade, enquanto exercentes do direito de defesa, da garantia da ordem jurídica e da democracia, o que inclui o seu trabalho em causas impopulares. Não são os únicos a serem malvistos por uma parte da população. Os médicos que o digam... São muitos os injustiçados pela crítica maledicente. $\mathrm{O}$ assistente social? É o profissional, com o qual, sem o qual, tudo continua tal e qual. Os arquitetos não são suficientemente homens para serem engenheiros, nem suficientemente "gays" para serem decoradores. Francesc Petit recorda em "Publicidade Ilimitada" a definição de Henri Miller: "Publicidade é a profissão formada de advogados fracassados, escritores frustrados, alcoólatras e artistas decadentes."

A advocacia dos Estados Unidos, cujo nível ético parece muito prejudicado, tem sido o alvo predileto das verrinas. Numa camiseta recente, trazida de lá, encontrei 15 perguntas (na frente) e 15 respostas (nas costas) que retratam o sentimento antiadvocacia. Três delas vão adiante. $\mathrm{O}$ que acontece quando cem advogados são enterrados na areia até o pescoço? Faltou areia. Por que os tubarões não comem advogados ? Solidariedade de classe. Por que todos os advogados foram para a Califórnia e todos os detritos tóxicos para New Jersey? New Jersey teve o direito de escolher primeiro.

Apesar dessas críticas, em geral os clientes são fiéis a seus profissionais. Continuam por muitos anos. Sabem que podem expor todos os seus problemas em confiança, sem temerem que seus segredos sejam revelados de modo ilícito. É o que sustento em meu livro "Segredos Profissionais" (Malheiros, 160 páginas), no qual discuto o sigilo do advogado, do médico, do bancário e do banqueiro, dos funcionários públicos.

Há quem estranhe que o advogado ouça segredos de clientes criminosos, mas ainda assim o defenda, silenciando sobre os delitos. Neste mundo tumultuário, a insegurança é tão grave, que muitos prefeririam sacrificar o direito de defesa alheio, em favor da segurança coletiva. É erro a evitar.

Os advogados sabem que os níveis éticos de seu trabalho estão rebaixados. Considerando o grande número de profissionais, a forte concorrência, a complicada 
luta pela vida, a insuficiência do ensino jurídico, o rebaixamento era inevitável. Todavia, apesar desse quadro negativo, a advocacia é - como, aliás, está na Constituição - função essencial da Justiça. É instrumento fundamental para garantir a cada um o que é seu, como convém assinalar na véspera do dia em que se comemora a instalação dos cursos jurídicos no Brasil.

Em termos da situação concreta, observamos que este artigo foi escrito às vésperas de um dia 11 de agosto, em 1996, dia do advogado e data da criação dos cursos de Direito no Brasil. O autor, Walter Ceneviva, foi colunista da Folha de $S$. Paulo por quase 30 anos, até novembro de 2013, assinando uma seção que se chamava Letras Jurídicas no caderno Cotidiano. Advogado e ex-professor de direito civil da PUC-SP, desde as primeiras colunas, como afirma em seu último texto ${ }^{5}$, teve o cuidado de tratar temas jurídicos em linguagem acessível, em textos que muitas vezes se aproximam de uma crônica. Como sabemos, a Folha, periódico paulista fundado em 1921, hoje o segundo jornal de maior circulação nacional no Brasil ${ }^{6}$ e um dos mais influentes, reserva espaços, em vários de seus cadernos cotidianos e especiais, para artigos de opinião assinados. Walter Ceneviva assinava aquele espaço a convite de Octavio Frias de Oliveira, empresário e sócio do jornal.

Quanto ao gênero artigo de opinião, é importante notar que não há, do ponto de vista da orientação do jornal, grandes recomendações para sua redação. $\mathrm{O} M a$ nual da redação da Folha de S. Paulo ensina apenas que o artigo assinado leva a opinião do autor, que se responsabiliza por seu conteúdo; e que o periódico só publica artigos inéditos (2010, p. 73; p. 109). O tema é de livre escolha do articulista. No caso desta seção - Letras jurídicas, a expectativa é que o assunto se relacione com o Direito, ainda que de forma ligeira, ou quase "literária". Em sua última colaboração na $F S P^{7}$, Walter Ceneviva conta um pouco das alterações do gênero ao longo dos anos, motivadas sobretudo pelo advento da informática (da paginação variável

\footnotetext{
5 http://wwwl folha.uol.com.br/colunas/walterceneviva/2013/11/1378860-da-primeira -a-ultima.shtm 1 Acesso em 03 de agosto de 2015.

6 Cf.: Os maiores jornais do brasil de circulação paga, por ano, com dados da Associação Nacional de Jornais: http://www.anj.org.br/maiores-jornais-do-brasil/ Acesso em 03 de agosto de 2015; http://www 1.folha.vol.com.br/mercado/2015/03/1600893-ivc-passa-a-se-chamar-instituto-verificador-de-comunicacao.shtml Acesso em 03 de agosto de 2015.

7 Cf. nota de rodapé n. 10.
} 
Linha D'Água (Online), São Paulo, v. 29, n. 2, p. 173-193, dez. 2016

aos espaços contados pelo número de toques no computador). Por aparecer numa página fixa e semanal, em que também constava a divulgação de obras jurídicas, em geral os artigos dirigiam-se de modo mais próximo a leitores específicos, que se interessavam por essa esfera de atividade ideológica, ainda que não participassem de qualquer dos ramos onde labutam os operadores do Direito ${ }^{8}$. Vejamos, então, como os sentidos se constroem nas relações dialógicas que o texto mantém com a situação mais ampla e mais próxima, diante das (poucas) coerções do gênero e da própria seleção léxica, gramatical e fraseológica.

Chama-nos a atenção, em primeiro lugar, a referência - e posterior citação -, à palavra do outro já no título: "Shakespeare disse tudo". E nos lembramos de que quase metade entre todas as palavras que pronunciamos são palavras de outros (BAKHTIN, 1993, p. 140), com as quais mantemos relaçôes dialógicas, concordando, refutando, acrescentando, concedendo... Assim, o próprio título do texto, literalmente, parece retomar e confirmar palavras do dramaturgo, asseverando que Shakespeare já dissera tudo, há muito tempo - “mais de 500 anos”, em termos de “críticas definitivas” à profissão dos advogados (1º. parágrafo).

A seguir, no segundo parágrafo, em discurso direto, o autor transcreve a frase contundente do "Bardo": "Para resolver os problemas do reino é necessário, em primeiro lugar, matar todos os advogados!" E, então, observamos claramente que, ao transmitir a "agressão shakesperiana", o locutor prepara apreciativamente a citação, precedendo-a por termos e expressões pejorativas do léxico em relação à atuação de tais profissionais - "alvos fáceis da crítica", que no parágrafo estão circundados por "criminosos", "casos controvertidos", ou políticos "execrados pela mídia". A transmissão dos versos do poeta leva em conta, como vemos, o leitor e o contexto cultural e social em que se apresentam, que tanto conhecem (e valorizam) o dramaturgo inglês como sabem (compartilham) das críticas a que estão sujeitos os advogados (e muitas vezes aqueles que são defendidos por eles).

8 Outra questão que não podemos recuperar aqui é aquela acerca do diálogo que este artigo encetava com os demais da mesma página e também com o próprio periódico, pois isso se altera bastante na versão que recuperamos na web la composição da página não mais está a cargo da editoração do jornal, mas de sua comercialização...). 
$\mathrm{Na}$ busca de conservar a integridade e autenticidade da citação, no parágrafo seguinte Ceneviva localiza a "agressão" na obra shakesperiana: "segunda parte do Henrique $6^{\circ}$., posta na voz de uma de seus personagens". E, coerente com seus propósitos, logo em seguida, o locutor concede-lhe razão no sentido de "espelhar a secular incompreensão com o papel dos advogados". A tese do autor, porém, já se delineia na entonação apreciativa bastante positiva com que apresenta o trabalho "persistente" do advogado, numa "missão" - um dever quase missionário (!), que é contrária ao que deles se afirma socialmente: "porta-vozes da sociedade, enquanto exercentes do direito de defesa, da garantia da ordem jurídica e da democracia, o que inclui o seu trabalho em causas impopulares". O enaltecimento da importância do trabalho do advogado, que se constitui garantia da ordem jurídica e da democracia, é a tese do autor. Mas é com base em uma possível concessão às críticas recebidas que o texto será desenvolvido, na medida em que o autor, retoricamente, parece conceder a elas o reconhecimento de sua legitimidade (cf. MOLINIÉ, 1992, p. 88), e somente lhes responde nos três parágrafos finais, que se inicia com a conjunção concessiva "Apesar dessas críticas...", concluindo e confirmando sua tese.

As relações dialógicas baseadas na concessão às críticas sociais referentes a diferentes profisssionais se multiplicam na continuidade do texto, servindo, afinal, aos propósitos do texto: independente das críticas, que podem ocorrer com qualquer profissão, em tempo - "há mais de 500 anos", e espaço tão distantes - não só no Brasil, mas também no mundo - diferentes estados dos Estados Unidos, como New Jersey ou Califórnia, "a advocacia é função essencial da Justiça”, como está na Constituição. As entonações apreciativas partem da orientação ativa do locutor, preenchendo as condições e as finalidades com as quais o texto foi redigido. Como pudemos perceber, os discursos citados, tanto aqueles de autoridades - de Shakespeare ou Henry Miller, como os ditos populares críticos e bem humorados em relação a outras profissões, se compreendem no todo do enunciado concreto, em sua relação com a situação próxima - do jornalismo "jurídico" semanal de um periódico não especializado, e também em relação com a situação mais ampla de celebração do dia do advogado e da criação dos cursos de Direito no país. 
Linha D'Água (Online), São Paulo, v. 29, n. 2, p. 173-193, dez. 2016

\subsection{Uma sentença judicial}

\section{DECISÃO}

Trata-se de auto de prisão em flagrante de Saul Rodrigues Rocha e Hagamenon Rodrigues Rocha, que foram detidos em virtude do suposto furto de duas (2) melancias. Instado a se manifestar, o Sr. Promotor de Justiça opinou pela manutenção dos indiciados na prisão.

Para conceder a liberdade aos indiciados, eu poderia invocar inúmeros fundamentos: os ensinamentos de Jesus Cristo, Buda e Ghandi, o Direito Natural, o princípio da insignificância ou bagatela, o princípio da intervenção mínima, os princípios do chamado Direito alternativo, o furto famélico, a injustiça da prisão de um lavrador e de um auxiliar de serviços gerais em contraposição à liberdade dos engravatados que sonegam milhões dos cofres públicos, o risco de se colocar os indiciados na Universidade do Crime (o sistema penitenciário nacional)...

Poderia sustentar que duas melancias não enriquecem nem empobrecem ninguém. Poderia aproveitar para fazer um discurso contra a situação econômica brasileira, que mantém $95 \%$ da população sobrevivendo com o mínimo necessário.

Poderia brandir minha ira contra os neoliberais, o consenso de Washington, a cartilha demagógica da esquerda, a utopia do socialismo, a colonização europeia....

Poderia dizer que George Bush joga bilhões de dólares em bombas na cabeça dos iraquianos, enquanto bilhões de seres humanos passam fome pela Terra - e aí, cadê a Justiça nesse mundo?

Poderia mesmo admitir minha mediocridade por não saber argumentar diante de tamanha obviedade.

Tantas são as possibilidades que ousarei agir em total desprezo às normas técnicas: não vou apontar nenhum desses fundamentos como razão de decidir. Simplesmente mandarei soltar os indiciados. Quem quiser que escolha o motivo.

Expeçam-se os alvarás. Intimem-se.

Palmas de Tocantins, .......... 2003.

X. Y. Z. Juiz de Direito 
$\mathrm{Na}$ esfera da atividade jurídica, a maioria dos gêneros é bastante padronizada e alguns deles sofrem coerções da própria legislação. É o caso da sentença judicial, cujas coerções do interior do enunciado estão prescritas no Código de Processo Penal, Art. 381-389. Basicamente ela deve se estruturar em três partes: relatório dos fatos, argumentos que irão motivar a decisão (princípios doutrinários do Direito, legislação, argumentação de modo geral - também a doxa) e, finalmente, o dispositivo ou decisão propriamente dita ${ }^{9}$. Nesta que transcrevemos - uma sentença judicial dos

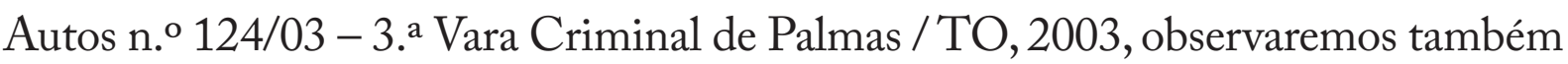
como as relações dialógicas e a entonação valorativa constituem a argumentação.

Do ponto de vista do exterior, as condições concretas em que se realiza qualquer sentença ligam-na ao contexto do fato gerador da ação judicial, levando as partes e a sociedade, de modo geral, a aceitá-la porque razoável e justa (ou não). Em outras palavras, a sentença dialoga cultural e socialmente com o tempo e o espaço em que foi emitida. Nesse sentido, para compreender a decisão, devemos também recuperar diferentes personagens, fatos e conceitos com os quais ela dialoga, atentando para a data e o local em que foi proferida.

O texto é predominantemente enunciativo, com abundância das marcas de pessoa, tempo e espaço, aquilo que Benveniste (2006) denominou aparelho formal da enunciação. O locutor - eu, é o juiz; o tempo é o momento presente, em que se encerra aquele processo, ano de 2003; o lugar, aqui, é o fórum da localidade onde correu o processo, Palmas de Tocantins. A entonação valorativa apresenta-se na seleção léxica, gramatical e fraseológica que direciona o dispositivo da sentença e vai mostrando, ao longo do todo texto, o posicionamento do juiz frente ao fato que julga: o furto de duas melancias.

Seguindo as coerções do gênero, o primeiro parágrafo da sentença apresenta sucintamente o relato dos fatos. Na realidade, não é o relatório do delito, mas da detenção de Saul Rodrigues Rocha e Hagamenon Rodrigues Rocha, "em virtude do suposto furto de duas melancias". Se observarmos as "formas da língua", veremos que o enunciador inicia o relatório na voz ativa: "Trata-se de auto de prisão em flagrante...", utilizando o sujeito indeterminado. Isso provoca seu distanciamento em relação

9 Interessante observar como a estrutura composicional do texto recupera a dispositio da antiga retórica: narração, confirmação e peroração. 
Linha D'Água (Online), São Paulo, v. 29, n. 2, p. 173-193, dez. 2016

ao ato cometido por outros agentes, aqueles responsáveis pela prisão dos indiciados. Aí, tanto o trata-se como o adjetivo suposto apontam para o não comprometimento do juiz-locutor com o fato - a prisão em flagrante, e já começam a mostrar ao leitor seu ponto de vista. Tal posicionamento pode continuar a ser observado, linguisticamente, por meio do uso da voz passiva analítica: "Saul... e Hagamenon... foram detidos..." Na voz passiva analítica, o sujeito sofre a ação verbal, diz a gramática; não é agente. Isto é, não estão expressos aí os agentes da ação de deter. É uma "Justiça" abstrata, que deve ser acatada pela sociedade, pois cumprindo seu papel. Ao relatar a atuação do Ministério Público, porém, o locutor utiliza a voz ativa: ele, o Promotor, é o responsável, pois posicionou-se pela "manutenção dos indiciados na prisão".

$\mathrm{Na}$ fundamentação, ao indicar os motivos de fato e de direito que fundamentarão a decisão, chama a atenção, primeiramente, não haver legislação ou jurisprudência, apenas princípios. Nesse sentido observamos a interação verbal do texto com as condições concretas em que se realiza: o diálogo do juiz, inicialmente, será com personagens universais da esfera religiosa, que têm em comum o apelo à convivência pacífica entre os homens - Jesus Cristo, Buda, Gandhi. Em seguida, o diálogo será com o próprio Direito, não em termos de legislação, mas de aspectos filosófico-doutrinários: o "Direito Natural, o princípio da insignificância ou bagatela, o princípio da intervenção mínima, os princípios do chamado Direito alternativo, o furto famélico”. Com exceção do conceito de Direito Natural ou da noção de furto famélico, que têm atravessado os séculos desde a Antiguidade, os demais dialogam com a contemporaneidade e o próprio Direito de forma crítica, pós-positivista. Aliás, a questão do furto famélico, aliada à pobreza, é retomada no parágrafo seguinte: "Poderia sustentar que duas melancias não enriquecem nem empobrecem ninguém”.

$\mathrm{Na}$ continuidade, novamente o diálogo tem como foco o próprio contexto social e político brasileiro, apresentado de um ponto de vista que, mais uma vez, não deixa qualquer dúvida quanto ao posicionamento que o juiz-locutor tomará no dispositivo: “... a injustiça da prisão de um lavrador e de um auxiliar de serviços gerais em contraposição à liberdade dos engravatados que sonegam milhões dos cofres públicos, o risco de se colocar os indiciados na Universidade do Crime (o sistema penitenciário nacional)...”. As condições concretas do texto, condições de crítica ao sistema prisonal e à impunidade daqueles que fazem parte do sistema 
Linha D'Água (Online), São Paulo, v. 29, n. 2, p. 173-193, dez. 2016

é ampliada e enfatizada no parágrafo seguinte: "Poderia aproveitar para fazer um discurso contra a situação econômica brasileira, que mantém 95\% da população sobrevivendo com o mínimo necessário".

Possibilidades argumentativas religiosas, doutrinárias, baseadas no contexto social, filosófico e político próximo dialogam, nos dois parágrafos seguintes, com o contexto social, filosófico e político distante, ironizando agora o neoliberalismo, a cartilha demagógica da esquerda, a utopia do socialismo, o Consenso de Washington, George Bush, etc... Observamos que o locutor/juiz dialoga criticamente com as vozes de seu tempo, posicionando-se contrariamente à guerra, à fome, a falta de Justiça no mundo. A busca de empatia com o leitor, por meio de uma compreensão responsivo-ativa com ele concordante é claramente buscada na interrogação que finaliza o parágrafo na modalidade coloquial, característica da oralidade, e distante da formalidade do Direito: "e aí, cadê a Justiça nesse mundo?"; e também na suposta admissão de "mediocridade por não saber argumentar diante de tamanha obviedade" expressa no antepenúltimo parágrafo.

$\mathrm{Na}$ realidade, observamos a figura da ironia no modo de apresentar os argumentos por meio da repetição de "Poderia invocar... Poderia sustentar... Poderia aproveitar...”: o verbo no futuro do pretérito dá um valor hipotético às possibilidades levantadas, apontando uma eventualidade possível. No entanto, sua repetição - recurso estilístico retórico que intensificaria a emoção do locutor, com vistas a mostrar sinceridade apaixonada, em vez de produzir um sentido de atenuação das possibilidades e competências indicadas, conduzem o interlocutor à conclusão esperada: “... ousarei agir em total desprezo às normas técnicas: não vou apontar nenhum desses fundamentos como razão de decidir". A análise, assim, descontrói o que está afirmado na superfície do texto como um desapego hipotético às regras do Direito e mesmo às coerções do gênero - as "normas técnicas". Isso porque os vários argumentos citados e não desenvolvidos caracterizam a figura retórica da preterição, figura de pensamento que consiste em dizer que não falaremos de uma coisa para melhor falar dela, exatamente o que sucede no texto. Segundo Reboul (1996), a preterição suscita a curiosidade e a conivência do leitor; provoca ainda certo estranhamento com a finalidade de chamar a atenção do interlocutor, visa à comunhão e à adesão do auditório sobre as premissas, que deve ser garantida antes de sua adesão relativamente ao 
Linha D'Água (Online), São Paulo, v. 29, n. 2, p. 173-193, dez. 2016

dispositivo, pois condição desta última. Quer dizer, os motivos de decidir, a fundamentação da sentença, estão claramente expressos do início ao fim do texto.

Ainda nesse parágrafo que constitui propriamente a decisão, o locutor novamente expressa de formas variadas sua valoração relativa ao fato que julga, como, por exemplo, ao "escolher" o leitor "diante de tantas possibilidades" - qualquer um, ou "Quem quiser...”. O interlocutor é construído no texto como seu igual, aquele que reconhece a "obviedade" dos motivos de decidir, o que reforça a decisão de soltar os indiciados. E enfim, a entonação apreciativa também pode ser detectada na forma como se apresentam os performativos que realizam a ação condenatória, primeiramente expressando a responsabilização do juiz pela ordem, utilizando o verbo na primeira pessoa: "Simplesmente mandarei soltar os indiciados". Para provocar o efeito de sentido de que a ação é óbvia e/ou não surpreendente, o locutor qualifica-a com o advérbio "simplesmente", deixando a noção deôntica se expressar por meio do futuro do Indicativo, indicador, entre outros valores, de que "se considera necessária (...) a ocorrência de um dado acontecimento num momento posterior ao presente..." (FIORIN, 2001, p. 154). Diferentemente desse, os performativos finais são burocráticos, expressos na voz passiva pronominal, não apresentam o agente: "Expeçam-se os alvarás. Intimem-se”.

Podemos verificar, afinal, que a compreensão mais detida do texto exige tanto conhecimentos discursivos, que vão além do verbal, constituindo o extraverbal, quanto linguísticos. $\mathrm{E}$ as relações dialógicas que o texto propõe voltam-se todas para a mesma direção crítica em relação à desigualdade social, indicando um posicionamento que já se percebe desde o início da sentença, por meio do que o pensamento bakhtiniano denomina entonação valorativa. $\mathrm{Na}$ realidade a sentença vai muito além da decisão de soltura de um lavrador e de um auxiliar de serviços gerais. Ela defende valores universais de maior igualdade social, de convivência pacífica entre os homens, de justiça social efetiva.

\section{Considerações finais}

As análises pretenderam mostrar o modo como algumas das principais categorias da teoria dialógica do discurso - dialogia, relações dialógicas, gênero do 
Linha D'Água (Online), São Paulo, v. 29, n. 2, p. 173-193, dez. 2016

discurso e entonação valorativa podem ser úteis na compreensão da argumentação. Desse modo, pudemos verificar que ambos os enunciados concretos - o artigo de opinião e a sentença judicial, estão intimamente ligado às condições concretas em que se realizam, tanto em termos composicionais, como em relação ao tema e ao estilo; respondem ainda a um momento histórico situado, com ele dialogando criticamente. Verificamos também como esses enunciados dialogam com as coerções do gênero, eventualmente se "insurgindo" contra as "normas técnicas”, como foi o caso da sentença, o que nos permite constatar a própria dinamicidade dos gêneros. Além disso, nestes textos esses diálogos se mostram persuasivos, na medida em que levam o interlocutor a compreender o papel do advogado, ou a hierarquizar como superior a preocupação com a injustiça e não uma possível obediência a regras processuais.

Outro aspecto importante que a análise aponta é o destaque ao exame das formas da língua na sua interpretação linguística habitual. Uma leitura apressada da obra bakhtiniana, principalmente de Marximo e flosofia da linguagem, no trecho em que Bakhtin/Volochínov tratam do "objetivismo abstrato", pode levar o leitor a imaginar que a obra do Círculo posiciona-se contrariamente à Linguística. Mas é essa própria obra que propõe que se examinem as "formas da língua". E devemos destacar que a crítica de Mikhail Bakhtin e o Círculo refere-se aos limites da Linguística, que a "metalinguística" permite suplantar, na medida em que seu foco é o discurso. Por isso, ambas "devem completar-se mutuamente e não fundir-se”.

Finalmente, é preciso lembrar que, por várias vezes, os membros do Círculo reconhecem a importância da antiga disciplina - a retórica, em sua obra. Nesta análise, nós só a utilizamos no reconhecimento do poder persuasivo de algumas das figuras utilizadas pelo locutor. A cooperação, contudo, pode ser maior, bastante ampla e produtiva.

\section{Referências}

ARISTÓTELES. Retórica. Prefácio e introdução de Manuel Alexandre Júnior. Trad. e notas de Manuel Alexandre Júnior et al. 3ed. Lisboa: Imprensa Nacional - Casa da Moeda, 2006. 
Linha D'Água (Online), São Paulo, v. 29, n. 2, p. 173-193, dez. 2016

BAKHTIN, Mikhail. (VOLOCHÍNOV, Valentin Nikolaevich.). Marxismo e filosofia da linguagem. Problemas fundamentais do método sociológico na ciência da linguagem. Trad. Michel Lahud e Yara Frateschi Vieira. São Paulo: Hucitec, 1981.

BAKHTIN, Mikhail. Os gêneros do discurso. Estética da Criação Verbal. 4 ed. Trad. Paulo Bezerra. São Paulo: Martins Fontes, 2006a, p. 261-306.

O problema do texto na linguística, na filologia e em outras ciências humanas. In Estética da Criação Verbal. 4ed. Trad. de Paulo Bezerra. São Paulo: Martins Fontes, 2006b, p. 307-336.

. Problemas da poética de Dostoiévski. 4ed. Revista e ampliada. Trad. Paulo Bezerra. Rio de Janeiro: Forense, 2008.

- A cultura popular na Idade Média e no Renascimento: o contexto de Fraçois Rabelais. Trad. Yara Frateschi. 4a. ed. São Paulo: Hucitec; Brasília: Edunb, 1999.

BENVENISTE, Émile. Problemas de linguística geral I. 5a. ed. Campinas, SP: Pontes, 2005, p. 81-90.

BIALOSTOSKY, Don. Aristotle's Rhetoric and Bakhtin's Discourse Theory. In: JOST, Walter; OLMSTED, Wendy (Ed.). A companion to rhetoric and rhetorical criticism. Malden, Ma; Oxford, Ox; Carlton, Victoria: Blackwell Publishing Ltd., 2004, p. 383-408.

BRAIT, Beth. Mikhail Bakhtin: autor e personagem. Revista USP, v. 39, n. 1, p. 158-173, 1998.

Análise e teoria do discurso. In: BRAIT, Beth. (org.). Bakbtin: outros conceitos-chave. São Paulo: Contexto, 2008: 9-31.

; MELO, Rosineide. Enunciado/enunciado concreto/enunciação. In: BRAIT, Beth. (org.). Bakbtin: conceitos-chave. 4.ed.São Paulo: Contexto 2008, p. 61-78.

; PISTORI, Maria Helena Cruz. A produtividade do conceito de gênero em Bakhtin e o Círculo. Alfa, Revista de linguística. (São José Rio Preto) [online]. 2012, vol.56, n.2, p. 371-401. <http://www.scielo.br/scielo.php?script=sci_arttext\&pi$\mathrm{d}=\mathrm{S} 1981-57942012000200002 \& \operatorname{lng}=\mathrm{en} \& \mathrm{nrm}=\mathrm{iso}>$. $\quad$ http://dx.doi.org/10.1590/S198157942012000200002 Acesso em 14 Set. 2014 
Linha D'Água (Online), São Paulo, v. 29, n. 2, p. 173-193, dez. 2016

FARACO, Carlos Alberto. Linguagem E̊ diálogo. As ideias linguísticas do Círculo de Bakhtin. São Paulo: Parábola Editorial, 2009.

FIORIN, José Luiz. As astúcias da enunciação. As categorias de pessoa, espaço e tempo. São Paulo: Ática, 2001.

MACHADO, Irene. Gêneros discursivos. In; BRAIT, Beth. (org.). Bakhtin: conceitos-chave. 4.ed. São Paulo: Contexto, 2008, p. 151-166.

MARROU, Henri-Irénée. História da educação na Antiguidade. Trad. Mário Leônidas Casanova. São Paulo: EPU, 1990.

MEDVIÉDEV. Pável Nikoláievitch. O método formal nos estudos literários. Introdução crítica a uma poética sociológica. Trad. Ekaterina Vólkova Américo e Sheila Camargo Grillo. São Paulo: Contexto, 2012, p. 193-207.

PISTORI, Maria Helena Cruz. Argumentação jurídica. Da antiga retórica a nossos dias. São Paulo: LTR, 2001.

Mikhail Bakhtin e Retórica: um diálogo possível e produtivo. Rétor. Asociación Argentina de Retórica. AAR, 2013, p. 60-85. http://www.revistaretor.org/pdf/retor0301_pistori.pdf Acesso em 14 Set. 2014.

REBOUL, O. Introdução à retórica. Trad. Ivone Castilho Benedetti. São Paulo: Martins Fontes, 2004.

ROJO, Roxane Helena Rodrigues. (2008); Gêneros de discurso/texto como objeto de ensino de línguas: Um retorno ao trivium? In: SIGNORINI, Inês. (org). [Re]Discutir texto, gênero e discurso. São Paulo: Parábola Editorial, p. 73-108.

ZANDWAIS, Ana. Bakhtin/Voloshínov: condições de produção de Marxismo e filosofia da linguagem. In: BRAIT, Beth. (org.). Bakhtin e o Círculo. São Paulo: Contexto, 2009, p. 97-116. 